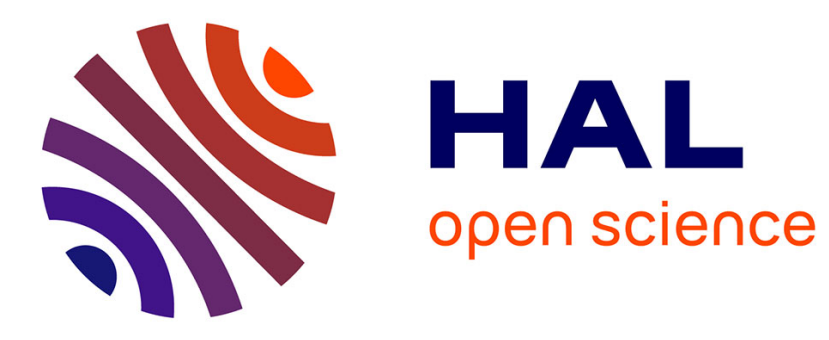

\title{
The Nociceptin/Orphanin FQ System and the Regulation of Memory
}

\author{
Lionel Moulédous
}

\section{To cite this version:}

Lionel Moulédous. The Nociceptin/Orphanin FQ System and the Regulation of Memory. The Nociceptin/Orphanin FQ peptide receptor, 254, pp.259-278, 2018, 10.1007/164_2018_185 . hal02351981

\section{HAL Id: hal-02351981 \\ https://hal.science/hal-02351981}

Submitted on 26 Nov 2019

HAL is a multi-disciplinary open access archive for the deposit and dissemination of scientific research documents, whether they are published or not. The documents may come from teaching and research institutions in France or abroad, or from public or private research centers.
L'archive ouverte pluridisciplinaire HAL, est destinée au dépôt et à la diffusion de documents scientifiques de niveau recherche, publiés ou non, émanant des établissements d'enseignement et de recherche français ou étrangers, des laboratoires publics ou privés. 
Handbook of Experimental Pharmacology

The Nociceptin/Orphanin FQ Peptide Receptor

Main Text: 6517 words

Table: 1

References: 90

\section{Chapter 12}

\section{The Nociceptin/OrphaninFQ system and the regulation of memory}

Lionel Moulédous

Research Center on Animal Cognition (CRCA), Center for Integrative Biology (CBI), Toulouse University, CNRS, UPS, France.

Lionel Moulédous, Research Center on Animal Cognition, UMR5169 CNRS, Université Paul

Sabatier, 118, route de Narbonne 31062 Toulouse Cedex 9, France; phone: +33 (0)5 61556429 , e-mail: lionel.mouledous@univ-tlse3.fr 


\section{Contents}

1. Introduction

2. Pharmacological modulation of learning and memory by NOP agonists

2.1. N/OFQ affects different types of long-term memory

2.2. Amnestic effects of systemic administration of NOP agonists

2.3. Different phases of long-term memory can be targeted

2.4. Promnesic effects of NOP agonists

3. Modulation of learning and memory by endogenous N/OFQ

3.1. Evidence from the study of receptor or precursor $\mathrm{KO}$ mice

3.2. Evidence from the study of the effect of NOP antagonists

4. Sites and mechanisms of action associated with the modulation of learning and memory by the N/OFQ system

4.1. The N/OFQ system in the hippocampus

4.2. The N/OFQ system in the amygdala

5. Conclusion - Future directions 


\begin{abstract}
Nociceptin/Orphanin FQ (N/OFQ) is an endogenous neuropeptide of 17 amino acids, related to opioid peptides but with its own receptor, distinct from conventional opioid receptors, the ORL1 or NOP receptor. The NOP receptor is a G protein-coupled receptor which activates Gi/o proteins and thus induces an inhibition of neuronal activity. The peptide and its receptor are widely expressed in the central nervous system with a high density of receptors in regions involved in learning and memory. This review describes the consequences of the pharmacological manipulation of the N/OFQ system by NOP receptor ligands on learning processes and on the consolidation of various types of long term memory. We also discuss the role of endogenous N/OFQ release in the modulation of learning and memory. Finally we propose several putative neuronal mechanisms taking place at the level of the hippocampus and amygdala and possibly underlying the behavioral amnestic or promnesic effects of NOP ligands.
\end{abstract}

Keywords: Nociceptin/orphaninFQ, long term memory, hippocampus, amygdala, druginduced amnesia, promnesic compound. 


\section{Introduction}

Nociceptin, also called orphanin FQ, (N/OFQ) is an endogenous peptide involved in numerous physiological functions at the level of the nervous, cardiovascular, respiratory, gastrointestinal, urinary and immune systems (Lambert 2008). Its receptor, ORL1 for opioidreceptor-like 1 or NOP, was first cloned by homology with opioid receptors (Mollereau et al. 1994). It is a G-protein coupled receptor of the rhodopsin family that has very strong homologies with classical mu (MOP), delta (DOP) and kappa (KOP) opioid receptors. However, it has a very low affinity for conventional opioid ligands such as morphine or enkephalins which initially made it an orphan receptor. A 17 amino acid peptide corresponding to N/OFQ was soon purified from rat and pig brain (Meunier et al. 1995; Reinscheid et al. 1995). The discovery of this system is therefore one of the first examples of reverse pharmacology. The peptide is very similar, in terms of sequence and charge, to the endogenous KOP agonist dynorphin A. It is derived from a protein precursor capable of releasing other peptides whose function remains unknown (Mollereau et al. 1996). The binding of N/OFQ to the NOP receptor leads to the activation of Gi/o inhibitory G proteins, with consequent inhibition of adenylyl cyclase and voltage-gated calcium channels, and activation of GIRK (inwardly rectifying) potassium channels (New and Wong 2002).

The development of ligands specific for the NOP receptor made it possible to study in preclinical models the major physiological functions and pathologies in which it is involved. At the level of the nervous system, the most promising, in terms of therapy, are the following (Lambert 2008): pain, drug dependence, Parkinson's disease, anxiety, depression and memory. Indeed the NOP receptor has a very wide distribution in the central nervous system (Mollereau and Mouledous 2000). It is present in the cortex, the thalamus, the limbic system (including the hippocampus (HPC), the septum, the nucleus of the stria terminalis (BNST), the amygdaloid 
complex, the hypothalamus, and monoaminergic nuclei (raphe nucleus, locus coeruleus, ventral tegmental area, substantia nigra). The neurons producing the precursor have a slightly more restricted distribution (Reinscheid et al. 2000), with strong expression in the BNST, the medial pre-optic area, the lateral septum and the medial and central amygdala (CeA). This distribution strongly suggests a role of the N/OFQ system at the interface between the control of stress and emotions (Fulford 2015; Gavioli and Calo 2013; Witkin et al. 2014) and memory processes (Andero 2015; Noda et al. 2000; Ouagazzal 2015) that are the main focus of this review article.

\section{Pharmacological modulation of learning and memory by NOP agonists}

\subsection{N/OFQ affects different types of long-term memory}

The first study on the effect of N/OFQ on memory was performed in rats and focused on spatial memory. It showed that the intra-hippocampus administration (in the CA3 region) of $10 \mathrm{nmol}$ of the peptide almost completely blocked the acquisition in the Morris Water Maze (MWM) (see Table 1 for a description of the behavioral paradigms). However, the possibility of confounding effects, notably related to a disturbance of the exploratory behavior of the animal by the peptide, was not totally ruled out (Sandin et al. 1997). It was subsequently shown that a lower dose of $3.3 \mathrm{nmol}$ injected into the HPC produced the same inhibition of learning without negative effect on exploration (Sandin et al. 2004). Normal learning in the visible platform version of the test also enabled the authors to rule out other confounding effects related to sensory perception or motivation. In addition, the co-administration of the NOP antagonist $\left[\mathrm{Nphe}^{1}\right] \mathrm{N} / \mathrm{OFQ}(1-13)-\mathrm{NH}_{2}$ (Calo et al. 2000) showed that this deleterious action on spatial learning was indeed mediated by the NOP receptor (Redrobe et al. 2000). The same negative impact on memory acquisition, specifically in the spatial version of the MWM, was observed 
in mice at doses of 5 and $10 \mathrm{nmol}$ after intra-cerebroventricular (icv) and $1 \mathrm{nmol}$ after intraCA3 injection (Kuzmin et al. 2009). Here again the consequences of N/OFQ injection were prevented by the administration of the $\left[\mathrm{Nphe}^{1}\right] \mathrm{N} / \mathrm{OFQ}(1-13)-\mathrm{NH}_{2}$ antagonist.

Other types of memory are also affected by the icv or intra-cerebral administration of the peptide. This was the case for contextual memory in the contextual fear conditioning test (CFC) for icv doses of 0.01 to $1 \mathrm{nmol}$ in mice (Mamiya et al. 2003) and 1 to $2.5 \mathrm{nmol}$ in rats (Fornari et al. 2008). The latter study also demonstrated that this amnestic effect was not due to a phenomenon of state dependence, meaning an integration of the interoceptive properties of the drug in the memory trace, since the memory was not restored when the test was performed in the presence of N/OFQ. On the other hand, N/OFQ was shown to be less active in the tone fear conditioning (TFC) paradigm (Mamiya et al. 2003) except at high dose (5 nmol) in rats (Fornari et al. 2008). Inhibitory avoidance (IA) is another aversive memory paradigm in which animal performances are affected by N/OFQ. In mice, 0.5 to $5 \mathrm{nmol}$ administered icv during the acquisition produced a decrease in the step-down latency during the retention test (Hiramatsu and Inoue 1999). A similar effect was observed for a dose of $0.5 \mathrm{nmol}$ in the stepthrough version of the test in rats, this amnestic action being blocked by the co-administration of $1 \mathrm{nmol}$ of $\left[\mathrm{Nphe}^{1}\right] \mathrm{N} / \mathrm{OFQ}(1-13)-\mathrm{NH}_{2}$ (Hiramatsu et al. 2008). Moreover icv doses of 1 and $4 \mathrm{nmol}$ delayed the acquisition in a multi-trial version of IA in mice, and this effect was again prevented by $\left[\mathrm{Nphe}^{1}\right] \mathrm{N} / \mathrm{OFQ}(1-13)-\mathrm{NH}_{2}$ (Liu et al. 2007). Signs of amnesia were also observed when the inhibitory avoidance phenomenon was evaluated in the elevated T-maze test (Asth et al. 2015). In rats, N/OFQ has also been injected intra-basolateral amygdala (BLA) in an IA paradigm, and doses of 1 to $100 \mathrm{pmol}$ have been shown to negatively affect memory retention performance (Roozendaal et al. 2007). The last type of memory on which the effect of N/OFQ has been tested is recognition memory. In the mouse object recognition (OR) test, the peptide 
injected icv (from $1 \mathrm{nmol}$ ) or intra-HPC ( $3 \mathrm{nmol}$, dorsal HPC) before learning induced memory deficits when retention was evaluated 24h later (Goeldner et al. 2008).

\subsection{Amnestic effects of systemic administration of NOP agonists}

Since the discovery of the N/OFQ system, several small systemically active NOP receptor agonists have been identified (Toll et al. 2016; Zaveri 2003). In the context of learning and memory, the vast majority of studies have been based on systemic administration of the NOP agonist Ro 64-6198 [(1S, 3aS)-8-(2,3,3a,4,5,6-hexahydro-1H-phenalen-1-yl)-1-phenyl1,3,8-triazaporo[4.5]decan-4-one], a compound developed by Roche (Wichmann et al. 2000). Overall, all the effects of icv administration of N/OFQ described above could be reproduced in rodents by intraperitoneal (ip) administration of Ro 64-6198 in a dose ranging from 0.3 to 3 $\mathrm{mg} / \mathrm{kg}$. Specifically, in mice, the compound impaired spatial learning in the MWM (Higgins et al. 2002; Kuzmin et al. 2009), fear conditioning to the context, but not to the tone (including in an immediate shock deficit paradigm which eliminates a possible confounding role of the anxiolytic properties of the NOP agonist) (Goeldner et al. 2009), learning in inhibitory avoidance (only at high dose) (Adem et al. 2017), as well as object recognition memory (Goeldner et al. 2008).

It is worth noting that the interpretation of the results obtained with Ro 64-6198 is complicated by the appearance of a sedative action for high doses with an impairment in motor performances (Jenck et al. 2000). This confounding effect has been excluded in some studies, for example by showing that learning was unaltered in the visible platform version of the MWM (Higgins et al. 2002; Kuzmin et al. 2009), or that short term memory was unaffected in the object recognition test (Goeldner et al. 2008). Beyond this putative nonspecific neurological impairment, it must also be taken into account that the selectivity of Ro 64-6198 for the NOP receptor is not optimal and that it interacts in particular, although with a 100-fold lower affinity, 
with the other members of the opioid receptor family (Jenck et al. 2000). Thus the inhibitory effect of the compound at $3 \mathrm{mg} / \mathrm{kg}$ in IA learning were not blocked by the $\left[\mathrm{Nphe}^{1}\right] \mathrm{N} / \mathrm{OFQ}(1-$ 13)- $\mathrm{NH}_{2}$ antagonist (Adem et al. 2017). Overall, it can be concluded that the effective doses are slightly higher than the doses producing anxiolytic effects and slightly lower than those provoking sedation (Jenck et al. 2000; Varty et al. 2005), indicating a relatively narrow therapeutic window for the amnestic action of the reference small molecule NOP agonist. It is therefore necessary to continue to improve the catalog of small NOP receptor agonist molecules, especially in terms of selectivity. In this framework, a recent study using the new compound SR-8993 (3 mg/kg ip) in the fear conditioning paradigm gave results partially in agreement with the reported effects of Ro 64-6198. Like the latter, SR-8993 inhibited context conditioning but contrary to Ro 64-6198 it also attenuated tone conditioning (Andero et al. 2013). This latest report also showed that the amnestic properties of the NOP agonist were conserved in a mouse model of dysregulated fear (Andero et al. 2013).

\subsection{Different phases of long-term memory can be targeted}

In most of the studies mentioned so far treatment with NOP agonists was carried out before learning and it was therefore difficult to know whether the amnestic effects observed were due to an inhibition of memory acquisition (encoding), consolidation (stabilization of the memory trace) or both. In the paradigms based on multiple trial learning like the MWM, it has been clearly demonstrated that the activation of NOP receptors interferes with the acquisition phase of the task (Higgins et al. 2002; Kuzmin et al. 2009; Redrobe et al. 2000; Sandin et al. 2004). This inhibition of acquisition could be linked to a perturbation of spatial working memory. Indeed, icv administration of 0.5 to $5 \mathrm{nmol}$ of N/OFQ decreased the performances, evaluated by spontaneous alternation, in the Y-maze (Hiramatsu and Inoue 1999). Similarly, using a multi-trial IA protocol, it was shown that icv N/OFQ delayed the acquisition of the task in mice (Liu et al. 2007). For the other paradigms for which NOP agonists have been tested the 
data suggest also an impairment of the memory consolidation phase. N/OFQ injected icv in mice after conditioning inhibited long-term memory retention in FC (Mamiya et al. 2003). The SR-8993 and Ro 65-6570 agonists also exhibited amnestic properties in FC when administered immediately after conditioning (Andero et al. 2013; Rekik et al. 2017). Similarly in IA in rats, intra-BLA injection of 1 to $100 \mathrm{pmol}$ of N/OFQ immediately or 3h (but not $6 \mathrm{~h}$ ) post-training impaired retention performance (Roozendaal et al. 2007). Finally, in the mouse OR paradigm, pretreatment with Ro 64-6198 disrupted the long-term memory tested 24 hours after learning but did not affect the short-term memory tested at 3 hours, which also suggests an action on the consolidation phase (Goeldner et al. 2008). It therefore seems that, depending to the type of memory considered, systemic or central activation of NOP receptors may interfere with the acquisition phase of memory, especially in spatial tasks and/or in procedures based on multitrial learning, or with its consolidation, especially for aversive and recognition memory.

The effects of NOP receptor activation on the later phases of long-term memory processes have been poorly studied. At doses known to affect the acquisition or consolidation processes, the agonists Ro 64-6198 and Ro 65-6570 did not inhibit memory retrieval in the object recognition and contextual fear conditioning paradigms respectively in mice (Goeldner et al. 2008; Rekik et al. 2017). Under certain circumstances, memory retrieval can cause a destabilization of the memory trace. The memory must then go through a process called reconsolidation to be stabilized again over time (Alberini and Ledoux 2013; Nader 2015). It has recently been shown that NOP agonists administered immediately after memory reactivation inhibit the reconsolidation of contextual fear memory in mice (Rekik et al. 2017). This effect was produced by both N/OFQ (3 nmol icv) and small molecule agonists Ro 65-6570 (1 mg/kg ip) and AT-403 (0.1 mg/kg ip), a recently discovered compound showing a high affinity and selectivity for NOP receptors (Ferrari et al. 2017). On the other hand, at the same doses, the two small agonist molecules were ineffective in interfering with the reconsolidation of tone fear 
memory suggesting that, as with fear memory consolidation, NOP receptor activation is more effective in interfering with contextual than cued fear memory reconsolidation (Rekik et al. 2017).

\subsection{Promnesic effects of NOP agonists}

Some studies have shown that very low doses of icv N/OFQ (10-100 fmol) could prevent the deleterious action of scopolamine in models of working memory (spontaneous alternation in Y-maze) and IA (Hiramatsu and Inoue 2000). Such promnesic effects have even been reported for doses as low as 1 fmol after intra-HPC injection (Miwa et al. 2009). However, it has since been shown that these properties were not mediated by the NOP receptor as they persisted in receptor $\mathrm{KO}$ mice, and the involvement of a metabolite of the peptide has been suggested (Miwa et al. 2010).

Other reports have demonstrated biphasic effects of icv (Adem et al. 2017) and intraHPC (Sandin et al. 2004) injection of N/OFQ. Thus, contrary to the amnestic actions obtained for the $3.3 \mathrm{nmol}$ intra-HPC dose in rats, intermediate doses of 0.33 to $1 \mathrm{nmol}$ facilitated learning in the MWM (Sandin et al. 2004). In addition, these promnesic effects were reversed by a NOP antagonist. Similarly in mice, it has been recently shown that icv administration of 1 or $10 \mathrm{nmol}$ of N/OFQ inhibited performance in the IA test, but that the $0.01 \mathrm{nmol}$ dose had a facilitating role (Adem et al. 2017). Thus, even though the majority of studies suggest that intermediate doses of NOP agonist are inactive in learning and memory paradigms, the above-mentioned work encourages further investigation of potential promnesic consequences of NOP receptor activation.

\section{Modulation of learning and memory by endogenous N/OFQ}


In view of the amnestic effects produced by the administration of NOP receptor agonists, it may be proposed that under certain circumstances the release of endogenous N/OFQ could inhibit learning and memory processes. A set of data from the study of NOP receptor or peptide precursor knockout $(\mathrm{KO})$ mice suggest that this is indeed the case.

\subsection{Evidence from the study of receptor or precursor KO mice}

The first constitutive NOP receptor knockout (NOP(-/-)) mouse line showed enhanced performances in terms of learning and memory. On the one hand memory acquisition was facilitated in the MWM test, $\mathrm{NOP}(-/-)$ mice learning faster than the $\mathrm{NOP}(+/+)$ mice, but showing no improvement in terms of retention of the spatial memory (Manabe et al. 1998). Similarly, in a KUROBOX system that makes it possible to test spatial learning with less stress than MWM, NOP(-/-) performed better than NOP(+/+) mice (Nagai et al. 2007). On the other hand, it is the memory retention that was increased in IA, with NOP(-/-) mice showing extended retention time compared to $\mathrm{NOP}(+/+)$ mice (Manabe et al. 1998). In the same way, in fear conditioning, contextual memory (but not the association of the electric shock with an auditory cue) was more durable in NOP(-/-) mice (Mamiya et al. 2003). Also, in the water-finding test, the same mouse line showed an enhancement of latent learning, compared to $\mathrm{NOP}(+/+)$ mice, that might be related to a decrease in dopamine content in the frontal cortex (Mamiya et al. 1998). Finally, NOP(-/-) mice showed no working memory improvement when evaluated by the alternation behavior in the Y-maze (Mamiya et al. 1999).

In contrast to the NOP KO (Manabe et al. 1998), the first study of ppN/OFQ precursor $\mathrm{KO}(\mathrm{ppN} / \mathrm{OFQ}(-/-))$ mice showed that they had wild type-like performances in the MWM (Koster et al. 1999). This discrepancy could be due to differences in the genetic background of the two lines or to a ceiling effect linked to differences in task difficulty between the two studies. 
It is also possible that the lack of performance improvement was due to the anxious phenotype of the ppN/OFQ(-/-) line, which is not observed in NOP(-/-) mice in the EPM test (Mamiya et al. 1998). Indeed, ppN/OFQ(-/-) mice showed abnormalities of response and adaptation to stress (Koster et al. 1999). These phenotypic differences between receptor and precursor KO mice could be linked to the deletion of the other two peptides present in the precursor sequence and whose target and function remain elusive (Mollereau et al. 1996). Anyway subsequent studies have managed to highlight an improvement in learning and memory processes in ppN/OFQ(-/) lines. The same $\mathrm{OFQ} / \mathrm{N}$ peptide deficient mice showed improved acquisition of the water maze task provided that the mice where single-housed, thus reducing chronic social stress (Higgins et al. 2002). ppN/OFQ(-/-) animals also performed better during reversal training in the MWM (Kuzmin et al. 2009). In terms of aversive memory, mice showed an increase in memory retention in FC and IA (Adem et al. 2017; Higgins et al. 2002), which is consistent with the NOP(-/-) mouse phenotype (Mamiya et al. 2003; Manabe et al. 1998).

The results obtained with the KO lines for the peptide or the receptor are globally consistent with the hypothesis of an inhibitory role of the N/OFQ system on various forms of learning and long-term memory. The study of constitutive KO, however, does not exclude the involvement of developmental adaptations in these animals and makes it difficult to identify the temporal phase of learning that is affected by the absence of receptor or peptide (learning rate vs memory retention). It is also possible that some of the apparent promnesic effects observed in constitutive $\mathrm{KO}$ mice do not result from a direct improvement of memory processes. A general increase in the level of arousal of the animals could for example indirectly increase acquisition and retrieval performances. The generation of conditional mutant mice could help addressing these questions. These limitations of genetic models can also be overcome by the use of pharmacological approaches based on NOP antagonists.

\subsection{Evidence from the study of the effect of NOP antagonists}


There are very few studies specifically designed to test the promnesic properties of NOP antagonists. In the majority of cases, the antagonists were used to reverse the amnestic effects of NOP agonists and thus to demonstrate that these properties were specific for the NOP receptor. These reports, however, included a control group treated by the antagonist alone and in the vast majority of cases this treatment is shown to have no effect on learning and memory. This was for example the case for the $\left[\mathrm{Nphe}^{1}\right] \mathrm{N} / \mathrm{OFQ}(1-13)-\mathrm{NH}_{2}$ antagonist at the dose of 50 nmol intra-HPC in rats (Redrobe et al. 2000) and $10 \mathrm{nmol}$ icv in mice (Kuzmin et al. 2009) on memory acquisition in the MWM. Similarly $10 \mathrm{nmol}$ of $\left[\mathrm{Nphe}^{1}\right] \mathrm{N} / \mathrm{OFQ}(1-13)-\mathrm{NH}_{2}$ icv in mice did not improve acquisition in IA (Liu et al. 2007). Another antagonist, UFP-101 (Calo et al. 2002), at the dose of $5 \mathrm{nmol}$ intra-HPC did not improve performances in the OR paradigm (Goeldner et al. 2008). On the contrary, it has been shown in the rat that post-training intraBLA injection of $10 \mathrm{pmol}$ of $\left[\mathrm{Nphe}^{1}\right] \mathrm{N} / \mathrm{OFQ}(1-13)-\mathrm{NH}_{2}$ increased memory retention in IA (Roozendaal et al. 2007). In addition, preliminary results suggested that the J-113397 antagonist (Kawamoto et al. 1999) ip at doses of 3 and $10 \mathrm{mg} / \mathrm{kg}$ in mice favored contextual learning in the immediate shock deficit paradigm and improves spontaneous alternations reflecting spatial working memory in the Y-maze (Ouagazzal 2015). The study of NOP antagonists therefore only partly confirms the hypothesis suggested by the characterization of KO mice, namely the possibility of improving memory performance by blocking the N/OFQ system. It must be emphasized, however, that most of the studies cited above were not aimed at the validation of the promnesic properties of NOP antagonists. In most cases, for example a single dose has been tested. In addition, the high performance of untreated control groups leaved little room for improved learning or memory retention in these studies. It seems therefore important to characterize further the potential promnesic effects of NOP antagonists, particularly in models in which the learning and memory capacities are altered. 


\section{Sites and mechanisms of action associated with the modulation of learning and memory by the N/OFQ system}

The N/OFQ system presents such a wide distribution in the brain that its effects on memory are probably mediated by a multitude of mechanisms involving many regions such as the hippocampus, the extended amygdala, the prefrontal cortex, some aminergic nuclei, some thalamic nuclei, the habenula (Gavioli and Calo 2013; Mollereau and Mouledous 2000; Witkin et al. 2014). In the following chapter we will focus on the direct actions of the peptide in two regions which are key for the types of long term memory that have been discussed in the previous sections, namely the hippocampus and the amygdala.

\subsection{The N/OFQ system in the hippocampus}

The hippocampus is probably a major site of action of the N/OFQ system for the modulation of learning and memory as evidenced by the amnestic effects of intra-HPC N/OFQ injections described above (Goeldner et al. 2008; Kuzmin et al. 2009; Sandin et al. 1997; Sandin et al. 2004). Numerous N/OFQ-containing interneurons are found in the dentate gyrus (DG) and CA1, CA2 and CA3 sub-regions of the rodent hippocampus (Ikeda et al. 1998; Neal et al. 1999b). By contrast the NOP receptor is expressed primarily on principal neurons in this area (Neal et al. 1999a). [ $\left.{ }^{3} \mathrm{H}\right] \mathrm{N} / \mathrm{OFQ}$ binding to rat and mouse brain sections is high in the stratum radiatum and oriens of the CA1 field, and moderate in the corresponding areas of the CA3 region and the DG molecular layer. It is much lower in the pyramidal and granular, and in the lacunosum moleculare layers (Higgins et al. 2002). This inhibitory system is therefore ideally placed to negatively modulate transmission and synaptic plasticity at the major relays of the hippocampal circuit. 
Thus, on slices of rat DG, N/OFQ has been shown to inhibit synaptic transmission at the level of the lateral perforant path-granule cell synapse by a mechanism involving post-synaptic hyperpolarization linked to activation $\mathrm{K}^{+}$currents ( $\mathrm{Yu}$ and Xie 1998). The peptide also inhibited the induction of long-term potentiation (LTP) by the high frequency stimulation of the lateral perforant path as well as the NMDA receptor-mediated excitatory post-synaptic currents (EPSCs) evoked by stimulation of this pathway. Here again the phenomenon seems postsynaptic since N/OFQ attenuated the inward currents evoked by focal application of NMDA (Yu and Xie 1998). N/OFQ induced changes in synaptic strength may actually be bi-directional since, at the same synapse in the mouse, another study has shown that the peptide also inhibited depotentiation and NMDA-dependent long-term depression (LTD) (Wei and Xie 1999).

In the principal cells of the CA3 region of the hippocampus, N/OFQ inhibited N, L and P/Q type voltage-gated calcium channels (Knoflach et al. 1996) et activated GIRK type potassium channels (Ikeda et al. 1997). In rat CA3 slices, the peptide showed inhibitory actions on epileptiform activity, with both presynaptic and postsynaptic sites of action (Tallent et al. 2001). In particular, it inhibited EPSCs generated by stimulation of mossy fibers but also associational/commissural fibers. At the post-synaptic level the increase of $\mathrm{K}^{+}$currents moved neurons away from their threshold for firing. But, unlike in the DG, presynaptic actions were also demonstrated, with a decrease in the frequency of miniature EPSCs (Tallent et al. 2001).

Finally, N/OFQ also increased $\mathrm{K}^{+}$currents in the principal cells of the CA1 region of the rat hippocampus (Madamba et al. 1999) and could therefore interfere with pyramidal cell activation and synaptic plasticity in this area. It is in fact at the Schaffer collateral/CA1 synapse that the electrophysiological properties of N/OFQ have been studied the most, especially by comparing the effects of the exogenous application of N/OFQ to those produced by the release of endogenous peptide. In rat hippocampal slices, exogenous N/OFQ inhibited synaptic transmission at the Schaffer collateral/CA1 level, probably by a presynaptic mechanism, as 
suggested by the increased paired-pulse facilitation (Yu et al. 1997). Another study also showed potentiation of feed-forward inhibition at the same synapse (Gutierrez et al. 2001). Subsequent work in the mouse also showed a depression of evoked population spikes but suggested a postsynaptic mechanism related to hyperpolarization of pyramidal cells via GIRK channel activation (Bongsebandhu-phubhakdi and Manabe 2007; Higgins et al. 2002). Regarding LTP, studies in rats and mice showed an inhibition of NMDA-dependent LTP induced by theta bursttype high frequency stimulations by exogenous N/OFQ (Higgins et al. 2002; Yu et al. 1997). This inhibition could be due to the hyperpolarization phenomena described above but could also involve a more direct regulation of NMDA receptor activity and signaling, and in particular an inhibition of kinases such as CamKII (Mamiya et al. 2003) and ERK (Goeldner et al. 2008). The role of endogenous N/OFQ was first studied in NOP(-/-)mice. In these animals, LTP induced by $100 \mathrm{~Hz}$ high-frequency tetanic stimulation of Schaffer collaterals was favored (Manabe et al. 1998). A subsequent study confirmed these results by showing that it was a form of NMDA-dependent LTP. The increase in LTP in these KO mice was probably of postsynaptic origin and was not found for lower frequency stimulation trains (20 and $50 \mathrm{~Hz}$ ) (Taverna et al. 2005). Bongsebandhu-phubhakdi and Manabe subsequently confirmed these results by showing an increase in $100 \mathrm{~Hz}$ tetanic stimulation induced LTP produced by the antagonist UFP-101 (Bongsebandhu-phubhakdi and Manabe 2007). In this case, UFP-101 opposed the inhibitory action of endogenous N/OFQ released at least in part from enkephalin-sensitive GABAergic interneurons. In contrast, no effect of the antagonist on basal synaptic transmission was demonstrated, suggesting the absence of basal N/OFQ tone. It is also interesting to note that UFP-101 did not affect theta burst induced LTP suggesting that there was no N/OFQ release under these conditions of Schaffer collateral stimulation (Bongsebandhu-phubhakdi and Manabe 2007). 
Overall, all of these investigations on hippocampus slices allow to draw several conclusions: 1) exogenous N/OFQ inhibits synaptic transmission and NMDA-dependent LTP by hyperpolarizing all types of principal cells, 2) the contribution of a presynaptic site of action is variable depending on the synapse and the species considered, 3) endogenous N/OFQ may have similar inhibitory effects, but it appears to be released only under particular stimulation conditions. Points 1 and 2 agree with the above behavioral data showing inhibitory actions of intra-HPC injection of N/OFQ on learning and memory (Goeldner et al. 2008; Kuzmin et al. 2009; Sandin et al. 1997; Sandin et al. 2004) and synergistic effects between the peptide and an NMDA antagonist (Goeldner et al. 2009; Goeldner et al. 2008). Point 3 implies that it will be very important to better characterize the physiological and pathological conditions of N/OFQ release in the hippocampus to identify the circumstances under which NOP antagonists might exert promnesic effects.

By acting mainly on the principal cells in the HPC, N/OFQ differs from conventional $\mu$ and $\delta$ opioids, which act indirectly by inhibiting GABAergic transmission (Bramham and Sarvey 1996). However, N/OFQ could still have an indirect mechanism of action but rather via the regulation of the release of cholinergic or monoaminergic mediators (Schlicker and Morari 2000). In this context, at the level of the hippocampus, only the modulation by N/OFQ of cholinergic signaling and its role in memory has been studied. Thus, it has been reported that N/OFQ inhibited the efflux of $\left[{ }^{3} \mathrm{H}\right]$ choline on electrically stimulated rat hippocampal slices (Cavallini et al. 2003) and that the icv injection of $0.5 \mathrm{nmol}$ of the peptide induced a sharp fall in acetylcholine release in the rat HPC (Hiramatsu et al. 2008). In addition, NOP KO mice had an increased baseline level of acetylcholine in the hippocampus, associated with enhanced (higher power) theta rhythms during wake and REM sleep (Uezu et al. 2005). However, at the behavioral level, no synergy could be demonstrated between the amnestic effects of N/OFQ and the cholinergic nicotinic receptor antagonist, mecamylamine, nor with the muscarinic 
receptor antagonist, scopolamine in the object recognition test, which suggests that the two systems do not interact in this paradigm (Reiss et al. 2012). Further studies will be needed to demonstrate a possible contribution of inhibition of acetylcholine release to the amnestic properties of the peptide in spatial and contextual memory paradigms.

A final way by which the hippocampal N/OFQ system could affect learning and memory is through the modulation of structural plasticity processes, i.e. adult neurogenesis in the DG or the plasticity of mature neurons. This hypothesis has not been studied in detail yet, but some indications suggest that it could be valid. Work done in vitro on primary cultures of embryonic hippocampal neurons produced conflicting results. Initially one study showed a positive effect of N/OFQ on the number and length of dendrites (Ring et al. 2006). On the contrary Alder et al have described more recently an inhibitory action of exogenous N/OFQ on dendritic growth, via an enhancement of the activity of RhoA, a small GTPase involved in cytoskeleton regulation (Alder et al. 2013). In vivo data are in agreement with this inhibitory effect of the peptide. Thus, an increase in the length of the primary dendrites and the number of spines of the granular cells of the DG was observed in ppN/OFQ(-/-) mice (Alder et al. 2013). In addition, a recent study has shown that repeated administration of the antagonist UFP-101 was able to increase the number of immature neurons positive for doublecortin in the DG of rats under chronic stress (Vitale et al. 2017). It can therefore be suggested that endogenous N/OFQ has a negative impact on the structural plasticity of mature neurons, but also on the generation of new neurons in the adult DG that contribute to spatial memory (Marin-Burgin and Schinder 2012).

N/OFQ therefore has negative effects on neuronal excitability and synaptic plasticity in the hippocampus. Its mechanism of action is not fully elucidated but may involve pre-synaptic inhibition of glutamate release and post-synaptic hyperpolarization, both processes being characteristic of Gi-coupled receptors. Finally the influence of N/OFQ on adult neurogenesis at the DG level and more generally on neuronal structural plasticity deserves further investigation. 


\subsection{The N/OFQ system in the amygdala}

Concerning the N/OFQ-sensitive aversive memory paradigms (FC, IA), the key region is the amygdala and in particular the basal and lateral nuclei (BLA) and the central nucleus (CeA). The BLA is the brain region where the processes of plasticity underlying emotional associative memory take place (association between the unconditioned stimulus, here the electric shock, and the conditioned stimulus, here the context or the tone) whereas the CeA is rather an output structure triggering conditioned behaviors (Johansen et al. 2011). The BLA and CeA contain N/OFQ labelled cell bodies and fibers (Neal et al. 1999b) and the NOP receptor is expressed in both regions (Neal et al. 1999a). As already mentioned systemic or icv administration of NOP agonists was more efficient in inhibiting the acquisition, consolidation and reconsolidation of hippocampus-dependent contextual aversive memory than that of amygdala-dependent cue aversive memory (Fornari et al. 2008; Goeldner et al. 2009; Mamiya et al. 2003; Rekik et al. 2017). However two studies have reported amnestic effects of intraamygdala injection of NOP ligands. In the rat, in the IA paradigm, 1 to $100 \mathrm{pmol}$ of N/OFQ administered in the BLA post-training impaired retention performance (Roozendaal et al. 2007). On the contrary, N/OFQ injection in the CeA was inactive. In the same report, it was show that intra-BLA administration of the NOP antagonist $\left[\mathrm{Nphe}^{1}\right] \mathrm{N} / \mathrm{OFQ}(1-13)-\mathrm{NH}_{2}$ increased memory performances and that this improvement was prevented by atenolol (an antagonist of the $\beta 1$-adrenergic receptor) (Roozendaal et al. 2007). This result suggests that endogenous N/OFQ prevents aversive memory consolidation by interfering with noradrenalin (NA) signaling. The second study, using the TFC paradigm in mice, demonstrated that intraCeA injection of the new NOP agonist SR-8993 inhibited memory consolidation (Andero et al. 2013). This data contrasts with the lack of effect of intra-CeA injection of N/OFQ reported by Roozendaal (Roozendaal et al. 2007). This apparent discrepancy could be explained by differences in species and behavioral paradigms or by the relatively high dose used in the mouse 
study that might have allowed diffusion of the drug from the CeA to the BLA. In any case, these behavioral data are in good agreement with the cellular actions of the peptide that have been described in this brain region. Similarly to the hippocampus both pre and post-synaptic actions have been reported. In rat brain slices, N/OFQ diminished evoked EPSCs in CeA neurons by a pre-synaptic mechanism (Kallupi et al. 2014). Moreover the opposite effect of the NOP antagonist $\left[\mathrm{Nphe}^{1}\right] \mathrm{N} / \mathrm{OFQ}(1-13)-\mathrm{NH}_{2}$ suggested that endogenous N/OFQ may tonically regulate basal spontaneous CeA glutamatergic activity (Kallupi et al. 2014). N/OFQ was also shown to inhibit pre-synaptically GABAergic synaptic transmission in CeA neurons (Roberto and Siggins 2006). Finally, also in the rat, N/OFQ hyperpolarized a fraction of CeA neurons projecting to the periaqueductal grey by enhancing an inwardly rectifying potassium conductance (Chen et al. 2009). A similar spectrum of actions has been described in the rat BLA with a partial suppression of evoked EPSCs and inhibitory post-synaptic currents (IPSCs) as well as spontaneous miniature EPSCs and IPSCs (Meis and Pape 2001), and a reduction of the excitability of the majority of class I projecting cells (Meis and Pape 1998). Besides glutamatergic and GABAergic transmission, and in agreement with the behavioral study cited above (Roozendaal et al. 2007), the modulation of the release of NA by the N/OFQ system has been described. Local infusion of the peptide in the BLA decreased NA levels measured by microdialysis by around 30\% whereas systemic administration of the NOP antagonist J-113397 doubled basal levels of the adrenergic transmitter (Kawahara et al. 2004).

\section{Conclusion - Future directions}

Both exogenous and endogenous N/OFQ clearly has a negative impact on learning and memory. These impairments appear to mainly affect context-dependent learning, to involve 
multiple regions including the HPC and the BLA, and to be mediated through pre- and postsynaptic inhibition of NMDA and noradrenergic signaling. So far three types of long term memory have been investigated: spatial memory in the MWM, aversive memory in the FC and IA paradigms and recognition memory in the OR test. Therefore an outstanding issue is the generality of the involvement of NOP receptor function in various forms of learning. Given its wide distribution the NOP receptor could be involved in a number of memory-related brain functions, not limited to hippocampus-dependent memory. Thus two forms of memory deserve further investigation, in particular because they have a major therapeutic interest. The first one is short-term memory and especially working memory. Studies suggest that N/OFQ could disrupt working memory evaluated by spontaneous alternation in the Y-maze (Hiramatsu and Inoue 1999) and delayed matching or delayed nonmatching to position tasks (Higgins et al. 2002) but the active doses are relatively high. This work should be completed to better characterize these effects and in particular their specificity. Similarly preliminary data suggest that the administration of NOP antagonists may favor working memory (Ouagazzal 2015) but here again more research is needed. The second form of memory for which the role of the N/OFQ system remains to be characterized is reward memory. The peptide was shown to prevent the development of conditioned place preference induced by abuse drugs such as opioids, stimulants and alcohol (Zaveri 2011). This inhibitory effect was proposed to be due to the anti-reward properties of the system. Indeed N/OFQ has been shown to reduce morphineand cocaine-induced release of dopamine in the nucleus accumbens (Di Giannuario et al. 1999; Lutfy et al. 2001). However, in order to develop a place preference, the animals have to learn the association between the rewarding properties of the drug and the context in which the drug is experienced. It is therefore possible that part of the inhibitory effect of N/OFQ in this task is due to an attenuation of associative contextual memory. NOP agonists could thus be useful to 
decrease the rewarding properties of drugs of abuse but also to weaken maladaptive drugassociated memories that can promote relapse (Milton and Everitt 2012).

This last point brings us to the question of the therapeutic perspectives of the N/OFQNOP receptor system in the field of learning and memory. Autoradiographic localization of N/OFQ binding sites in macaque brain demonstrated that similarly to rodents the NOP receptor is highly expressed in the hippocampus and the amygdala in primates, suggesting a conservation of memory-modulating properties of the peptide across species (Bridge et al. 2003). A moderate to high expression of NOP receptors has also been demonstrated in principal cells of the DG, CA1 and CA3 in the human brain (Berthele et al. 2003). Polymorphisms or changes in NOP receptor expression have been associated with various neuropsychiatric conditions in human such as PTSD (Andero et al. 2013), alcohol dependence (Huang et al. 2008), opiate addiction (Briant et al. 2010) and suicide (Lutz et al. 2015) but, so far, not with pathologies characterized by deficits in learning and memory. Based on the preclinical data, one might suggest that NOP agonists could be useful as amnestic drugs for disorders associated with maladaptive memories such as PTSD and addiction. This hope, however, must be tempered by the fact that NOP agonists can be predicted to interfere more efficiently with hippocampus-dependent episodic memories than amygdala-dependent emotional memories. It is also important to note that, although several clinical trials have been performed, no NOP-selective agonist has been advanced into phase II (cebranopadol, a phase III analgesic compound is a mixed NOP-MOP agonist) (Zaveri 2016), one main concern being the narrow therapeutic window before sedative effects are observed in patients. More promising may be the use of NOP antagonists as memory enhancers. A recent study reported the NOP antagonist LY2940094 to be safe and well tolerated and to show some efficacy in reducing symptoms of depression in Major Depressive Disorder patients (Post et al. 2016). Another phase II study is underway with a higher dosage of the compound for the same pathology (ClinicalTrials.gov Identifier: NCT03193398). Provided that 
the promnesic properties of NOP antagonists are better characterized in preclinical models, it seems therefore realistic to envision testing such molecules in the future to improve learning and memory in patients suffering from cognitive deficits associated with neuropsychiatric or neurodegenerative diseases.

\section{References}

Adem A, Madjid N, Kahl U, Holst S, Sadek B, Sandin J, Terenius L, Ogren SO (2017) Nociceptin and the NOP receptor in aversive learning in mice. Eur Neuropsychopharmacol 27: 1298-1307.

Alberini CM, Ledoux JE (2013) Memory reconsolidation. Curr Biol 23: R746-50.

Alder J, Kallman S, Palmieri A, Khadim F, Ayer JJ, Kumar S, Tsung K, Grinberg I, ThakkerVaria S (2013) Neuropeptide orphanin FQ inhibits dendritic morphogenesis through activation of RhoA. Dev Neurobiol 73: 769-84.

Andero R (2015) Nociceptin and the nociceptin receptor in learning and memory. Progress in neuro-psychopharmacology \& biological psychiatry 62: 45-50.

Andero R, Brothers SP, Jovanovic T, Chen YT, Salah-Uddin H, Cameron M, Bannister TD, Almli L, Stevens JS, Bradley B, Binder EB, Wahlestedt C, Ressler KJ (2013) Amygdala-dependent fear is regulated by Oprl1 in mice and humans with PTSD. Science translational medicine 5: $188 \mathrm{ra} 73$.

Asth L, Correia N, Lobao-Soares B, De Lima TC, Guerrini R, Calo G, Soares-Rachetti VP, Gavioli EC (2015) Nociceptin/orphanin FQ induces simultaneously anxiolytic and amnesic effects in the mouse elevated T-maze task. Naunyn Schmiedebergs Arch Pharmacol 388: 33-41. 
Berthele A, Platzer S, Dworzak D, Schadrack J, Mahal B, Buttner A, Assmus HP, Wurster K, Zieglgansberger W, Conrad B, Tolle TR (2003) [3H]-nociceptin ligand-binding and nociceptin opioid receptor mrna expression in the human brain. Neuroscience 121: 62940.

Bongsebandhu-phubhakdi S, Manabe T (2007) The neuropeptide nociceptin is a synaptically released endogenous inhibitor of hippocampal long-term potentiation. J Neurosci 27: 4850-8.

Bramham CR, Sarvey JM (1996) Endogenous activation of mu and delta-1 opioid receptors is required for long-term potentiation induction in the lateral perforant path: dependence on GABAergic inhibition. J Neurosci 16: 8123-31.

Briant JA, Nielsen DA, Proudnikov D, Londono D, Ho A, Ott J, Kreek MJ (2010) Evidence for association of two variants of the nociceptin/orphanin FQ receptor gene OPRL1 with vulnerability to develop opiate addiction in Caucasians. Psychiatric genetics 20: 65-72.

Bridge KE, Wainwright A, Reilly K, Oliver KR (2003) Autoradiographic localization of (125)i[Tyr(14)] nociceptin/orphanin FQ binding sites in macaque primate CNS. Neuroscience 118: 513-23.

Calo G, Guerrini R, Bigoni R, Rizzi A, Marzola G, Okawa H, Bianchi C, Lambert DG, Salvadori S, Regoli D (2000) Characterization of [Nphe(1)]nociceptin(1-13)NH(2), a new selective nociceptin receptor antagonist. Br J Pharmacol 129: 1183-93.

Calo G, Rizzi A, Rizzi D, Bigoni R, Guerrini R, Marzola G, Marti M, McDonald J, Morari M, Lambert DG, Salvadori S, Regoli D (2002) [Nphe1,Arg14,Lys15]nociceptin-NH2, a novel potent and selective antagonist of the nociceptin/orphanin FQ receptor. $\mathrm{Br} \mathbf{J}$ Pharmacol 136: 303-11.

Cavallini S, Marino S, Beani L, Bianchi C, Siniscalchi A (2003) Nociceptin inhibition of acetylcholine efflux from different brain areas. Neuroreport 14: 2167-70. 
Chen YL, Li AH, Yeh TH, Chou AH, Wang HL (2009) Nocistatin and nociceptin exert opposite effects on the excitability of central amygdala nucleus-periaqueductal gray projection neurons. Mol Cell Neurosci 40: 76-88.

Di Giannuario A, Pieretti S, Catalani A, Loizzo A (1999) Orphanin FQ reduces morphineinduced dopamine release in the nucleus accumbens: a microdialysis study in rats. Neurosci Lett 272: 183-6.

Ferrari F, Malfacini D, Journigan BV, Bird MF, Guerrini R, Lambert DG, Calo G, Zaveri NT (2017) In vitro pharmacological characterization of a novel unbiased NOP receptorselective nonpeptide agonist AT-403. Pharmacol Res Perspect

Fornari RV, Soares JC, Ferreira TL, Moreira KM, Oliveira MG (2008) Effects of nociceptin/orphanin FQ in the acquisition of contextual and tone fear conditioning in rats. Behav Neurosci 122: 98-106.

Fulford AJ (2015) Endogenous nociceptin system involvement in stress responses and anxiety behavior. Vitamins and hormones 97: 267-93.

Gavioli EC, Calo G (2013) Nociceptin/orphanin FQ receptor antagonists as innovative antidepressant drugs. Pharmacol Ther 140: 10-25.

Goeldner C, Reiss D, Wichmann J, Kieffer BL, Ouagazzal AM (2009) Activation of nociceptin opioid peptide (NOP) receptor impairs contextual fear learning in mice through glutamatergic mechanisms. Neurobiol Learn Mem 91: 393-401.

Goeldner C, Reiss D, Wichmann J, Meziane H, Kieffer BL, Ouagazzal AM (2008) Nociceptin receptor impairs recognition memory via interaction with NMDA receptor-dependent mitogen-activated protein kinase/extracellular signal-regulated kinase signaling in the hippocampus. J Neurosci 28: 2190-8. 
Gutierrez R, Leff P, Romo-Parra H, Acevedo R, Anton B (2001) Orphanin-FQ/nociceptin inhibits kindling epileptogenesis and enhances hippocampal feed-forward inhibition. Neuroscience 105: 325-33.

Higgins GA, Kew JN, Richards JG, Takeshima H, Jenck F, Adam G, Wichmann J, Kemp JA, Grottick AJ (2002) A combined pharmacological and genetic approach to investigate the role of orphanin FQ in learning and memory. Eur J Neurosci 15: 911-22.

Hiramatsu M, Inoue K (1999) Effects of nocistatin on nociceptin-induced impairment of learning and memory in mice. Eur J Pharmacol 367: 151-5.

Hiramatsu M, Inoue K (2000) Improvement by low doses of nociceptin on scopolamineinduced impairment of learning and/or memory Eur J Pharmacol 395: 149-56.

Hiramatsu M, Miwa M, Hashimoto K, Kawai S, Nomura N (2008) Nociceptin/orphanin FQ reverses mecamylamine-induced learning and memory impairment as well as decrease in hippocampal acetylcholine release in the rat. Brain Res 1195: 96-103.

Huang J, Young B, Pletcher MT, Heilig M, Wahlestedt C (2008) Association between the nociceptin receptor gene (OPRL1) single nucleotide polymorphisms and alcohol dependence. Addict Biol 13: 88-94.

Ikeda K, Kobayashi K, Kobayashi T, Ichikawa T, Kumanishi T, Kishida H, Yano R, Manabe T (1997) Functional coupling of the nociceptin/orphanin FQ receptor with the Gprotein-activated K+ (GIRK) channel. Brain Res Mol Brain Res 45: 117-26.

Ikeda K, Watanabe M, Ichikawa T, Kobayashi T, Yano R, Kumanishi T (1998) Distribution of prepro-nociceptin/orphanin FQ mRNA and its receptor mRNA in developing and adult mouse central nervous systems. J Comp Neurol 399: 139-51.

Jenck F, Wichmann J, Dautzenberg FM, Moreau JL, Ouagazzal AM, Martin JR, Lundstrom K, Cesura AM, Poli SM, Roever S, Kolczewski S, Adam G, Kilpatrick G (2000) A 
synthetic agonist at the orphanin FQ/nociceptin receptor ORL1: Anxiolytic profile in the rat. Proc Natl Acad Sci U S A 97: 4938-4943.

Johansen JP, Cain CK, Ostroff LE, LeDoux JE (2011) Molecular mechanisms of fear learning and memory. Cell 147: 509-24.

Kallupi M, Varodayan FP, Oleata CS, Correia D, Luu G, Roberto M (2014) Nociceptin/orphanin FQ decreases glutamate transmission and blocks ethanol-induced effects in the central amygdala of naive and ethanol-dependent rats. Neuropsychopharmacology 39: 1081-92.

Kawahara Y, Hesselink MB, van Scharrenburg G, Westerink BH (2004) Tonic inhibition by orphanin $\mathrm{FQ} /$ nociceptin of noradrenaline neurotransmission in the amygdala. Eur $\mathbf{J}$ Pharmacol 485: 197-200.

Kawamoto H, Ozaki S, Itoh Y, Miyaji M, Arai S, Nakashima H, Kato T, Ohta H, Iwasawa Y (1999) Discovery of the first potent and selective small molecule opioid receptor-like (ORL1) antagonist: 1-[(3R,4R)-1-cyclooctylmethyl-3- hydroxymethyl-4-piperidyl]-3ethyl- 1, 3-dihydro-2H-benzimidazol-2-one (J-113397) [In Process Citation]. J Med Chem 42: 5061-3.

Knoflach F, Reinscheid RK, Civelli O, Kemp JA (1996) Modulation of voltage-gated calcium channels by orphanin FQ in freshly dissociated hippocampal neurons. J Neurosci 16: 6657-64.

Koster A, Montkowski A, Schulz S, Stube EM, Knaudt K, Jenck F, Moreau JL, Nothacker HP, Civelli O, Reinscheid RK (1999) Targeted disruption of the orphanin FQ/nociceptin gene increases stress susceptibility and impairs stress adaptation in mice. Proc Natl Acad Sci U S A 96: 10444-9. 
Kuzmin A, Madjid N, Johansson B, Terenius L, Ogren SO (2009) The nociceptin system and hippocampal cognition in mice: a pharmacological and genetic analysis. Brain Res 1305 Suppl: S7-19.

Lambert DG (2008) The nociceptin/orphanin FQ receptor: a target with broad therapeutic potential. Nat Rev Drug Discov 7: 694-710.

Liu EH, Lee TL, Nishiuchi Y, Kimura T, Tachibana S (2007) Nocistatin and its derivatives antagonize the impairment of short-term acquisition induced by nociceptin. Neurosci Lett 416: 155-9.

Lutfy K, Do T, Maidment NT (2001) Orphanin FQ/nociceptin attenuates motor stimulation and changes in nucleus accumbens extracellular dopamine induced by cocaine in rats. Psychopharmacology (Berl) 154: 1-7.

Lutz PE, Zhou Y, Labbe A, Mechawar N, Turecki G (2015) Decreased expression of nociceptin/orphanin FQ in the dorsal anterior cingulate cortex of suicides. Eur Neuropsychopharmacol 25: 2008-14.

Madamba SG, Schweitzer P, Siggins GR (1999) Nociceptin augments K(+) currents in hippocampal CA1 neurons by both ORL-1 and opiate receptor mechanisms. J Neurophysiol 82: 1776-85.

Mamiya T, Noda Y, Nishi M, Takeshima H, Nabeshima T (1998) Enhancement of spatial attention in nociceptin/orphanin FQ receptor- knockout mice Brain Res 783: 236-40.

Mamiya T, Noda Y, Nishi M, Takeshima H, Nabeshima T (1999) Nociceptin system plays a role in the memory retention: involvement of naloxone benzoylhydrazone binding sites. Neuroreport 10: 1171-5.

Mamiya T, Yamada K, Miyamoto Y, Konig N, Watanabe Y, Noda Y, Nabeshima T (2003) Neuronal mechanism of nociceptin-induced modulation of learning and memory: involvement of N-methyl-D-aspartate receptors. Molecular psychiatry 8: 752-65. 
Manabe T, Noda Y, Mamiya T, Katagiri H, Houtani T, Nishi M, Noda T, Takahashi T, Sugimoto T, Nabeshima T, Takeshima H (1998) Facilitation of long-term potentiation and memory in mice lacking nociceptin receptors. Nature 394: 577-81.

Marin-Burgin A, Schinder AF (2012) Requirement of adult-born neurons for hippocampusdependent learning. Behav Brain Res 227: 391-9.

Meis S, Pape HC (1998) Postsynaptic mechanisms underlying responsiveness of amygdaloid neurons to nociceptin/orphanin FQ. J Neurosci 18: 8133-44.

Meis S, Pape HC (2001) Control of glutamate and GABA release by nociceptin/orphanin FQ in the rat lateral amygdala. J Physiol 532: 701-12.

Meunier JC, Mollereau C, Toll L, Suaudeau C, Moisand C, Alvinerie P, Butour JL, Guillemot JC, Ferrara P, Monsarrat B, et al. (1995) Isolation and structure of the endogenous agonist of opioid receptor- like ORL1 receptor Nature 377: 532-5.

Milton AL, Everitt BJ (2012) The persistence of maladaptive memory: addiction, drug memories and anti-relapse treatments. Neurosci Biobehav Rev 36: 1119-39.

Miwa M, Shinki C, Uchida S, Hiramatsu M (2009) Distinct effects of nociceptin analogs on scopolamine-induced memory impairment in mice. Eur J Pharmacol 602: 328-33.

Miwa M, Uchida S, Horiba F, Takeshima H, Nabeshima T, Hiramatsu M (2010) Nociceptin and its metabolite attenuate U0126-induced memory impairment through a nociceptin opioid peptide (NOP) receptor-independent mechanism. Neurobiol Learn Mem 93: 396405.

Mollereau C, Mouledous L (2000) Tissue distribution of the opioid receptor-like (ORL1) receptor. Peptides 21: 907-17.

Mollereau C, Parmentier M, Mailleux P, Butour JL, Moisand C, Chalon P, Caput D, Vassart G, Meunier JC (1994) ORL1, a novel member of the opioid receptor family. Cloning, functional expression and localization. FEBS Lett 341: 33-8. 
Mollereau C, Simons MJ, Soularue P, Liners F, Vassart G, Meunier JC, Parmentier M (1996) Structure, tissue distribution, and chromosomal localization of the prepronociceptin gene. Proc Natl Acad Sci U S A 93: 8666-70.

Nader K (2015) Reconsolidation and the Dynamic Nature of Memory. Cold Spring Harbor perspectives in biology 7 .

Nagai J, Kurokawa M, Takeshima H, Kieffer BL, Ueda H (2007) Circadian-dependent learning and memory enhancement in nociceptin receptor-deficient mice with a novel KUROBOX apparatus using stress-free positive cue task. J Pharmacol Exp Ther 321: 195-201.

Neal CR, Jr., Mansour A, Reinscheid R, Nothacker HP, Civelli O, Akil H, Watson SJ, Jr. (1999a) Opioid receptor-like (ORL1) receptor distribution in the rat central nervous system: comparison of ORL1 receptor mRNA expression with (125)I- [(14)Tyr]orphanin FQ binding [In Process Citation]. J Comp Neurol 412: 563-605.

Neal CR, Jr., Mansour A, Reinscheid R, Nothacker HP, Civelli O, Watson SJ, Jr. (1999b) Localization of orphanin FQ (nociceptin) peptide and messenger RNA in the central nervous system of the rat. J Comp Neurol 406: 503-47.

New DC, Wong YH (2002) The ORL1 receptor: molecular pharmacology and signalling mechanisms. Neurosignals 11: 197-212.

Noda Y, Mamiya T, Manabe T, Nishi M, Takeshima H, Nabeshima T (2000) Role of nociceptin systems in learning and memory. Peptides 21: 1063-9.

Ouagazzal AM (2015) Nociceptin/Orphanin-FQ Modulation of Learning and Memory. Vitamins and hormones 97: 323-45.

Post A, Smart TS, Krikke-Workel J, Dawson GR, Harmer CJ, Browning M, Jackson K, Kakar R, Mohs R, Statnick M, Wafford K, McCarthy A, Barth V, Witkin JM (2016) A 
Selective Nociceptin Receptor Antagonist to Treat Depression: Evidence from Preclinical and Clinical Studies. Neuropsychopharmacology 41: 1803-12.

Redrobe JP, Calo G, Guerrini R, Regoli D, Quirion R (2000) [Nphe(1)]-Nociceptin (1-13)$\mathrm{NH}(2)$, a nociceptin receptor antagonist, reverses nociceptin-induced spatial memory impairments in the Morris water maze task in rats. Br J Pharmacol 131: 1379-84.

Reinscheid RK, Nothacker H, Civelli O (2000) The orphanin FQ/nociceptin gene: structure, tissue distribution of expression and functional implications obtained from knockout mice. Peptides 21: 901-6.

Reinscheid RK, Nothacker HP, Bourson A, Ardati A, Henningsen RA, Bunzow JR, Grandy DK, Langen H, Monsma FJ, Jr., Civelli O (1995) Orphanin FQ: a neuropeptide that activates an opioidlike G protein- coupled receptor. Science 270: 792-4.

Reiss D, Prinssen EP, Wichmann J, Kieffer BL, Ouagazzal AM (2012) The nociceptin orphanin FQ peptide receptor agonist, Ro64-6198, impairs recognition memory formation through interaction with glutamatergic but not cholinergic receptor antagonists. Neurobiol Learn Mem 98: 254-60.

Rekik K, Faria Da Silva R, Colom M, Pacifico S, Zaveri NT, Calo G, Rampon C, Frances B, Mouledous L (2017) Activation of nociceptin/orphanin FQ receptors inhibits contextual fear memory reconsolidation. Neuropharmacology 125: 39-49.

Ring RH, Alder J, Fennell M, Kouranova E, Black IB, Thakker-Varia S (2006) Transcriptional profiling of brain-derived-neurotrophic factor-induced neuronal plasticity: a novel role for nociceptin in hippocampal neurite outgrowth. J Neurobiol 66: 361-77.

Roberto M, Siggins GR (2006) Nociceptin/orphanin FQ presynaptically decreases GABAergic transmission and blocks the ethanol-induced increase of GABA release in central amygdala. Proc Natl Acad Sci U S A 103: 9715-20. 
Roozendaal B, Lengvilas R, McGaugh JL, Civelli O, Reinscheid RK (2007) Orphanin $\mathrm{FQ}$ /nociceptin interacts with the basolateral amygdala noradrenergic system in memory consolidation. Learn Mem 14: 29-35.

Sandin J, Georgieva J, Schott PA, Ogren SO, Terenius L (1997) Nociceptin/orphanin FQ microinjected into hippocampus impairs spatial learning in rats. Eur J Neurosci 9: 1947.

Sandin J, Ogren SO, Terenius L (2004) Nociceptin/orphanin FQ modulates spatial learning via ORL-1 receptors in the dorsal hippocampus of the rat. Brain Res 997: 222-33.

Schlicker E, Morari M (2000) Nociceptin/orphanin FQ and neurotransmitter release in the central nervous system. Peptides 21: 1023-9.

Tallent MK, Madamba SG, Siggins GR (2001) Nociceptin reduces epileptiform events in CA3 hippocampus via presynaptic and postsynaptic mechanisms. J Neurosci 21: 6940-8.

Taverna FA, Georgiou J, McDonald RJ, Hong NS, Kraev A, Salter MW, Takeshima H, Muller RU, Roder JC (2005) Defective place cell activity in nociceptin receptor knockout mice with elevated NMDA receptor-dependent long-term potentiation. J Physiol 565: 57991.

Toll L, Bruchas MR, Calo G, Cox BM, Zaveri NT (2016) Nociceptin/Orphanin FQ Receptor Structure, Signaling, Ligands, Functions, and Interactions with Opioid Systems. Pharmacol Rev 68: 419-57.

Uezu K, Sano A, Sei H, Toida K, Houtani T, Sugimoto T, Suzuki-Yamamoto T, Takeshima H, Ishimura K, Morita Y (2005) Enhanced hippocampal acetylcholine release in nociceptin-receptor knockout mice. Brain Res 1050: 118-23.

Varty GB, Hyde LA, Hodgson RA, Lu SX, McCool MF, Kazdoba TM, Del Vecchio RA, Guthrie DH, Pond AJ, Grzelak ME, Xu X, Korfmacher WA, Tulshian D, Parker EM, Higgins GA (2005) Characterization of the nociceptin receptor (ORL-1) agonist, Ro64- 
6198 , in tests of anxiety across multiple species. Psychopharmacology (Berl) 182: 13243.

Vitale G, Filaferro M, Micioni Di Bonaventura MV, Ruggieri V, Cifani C, Guerrini R, Simonato M, Zucchini S (2017) Effects of [Nphe1, Arg14, Lys15] N/OFQ-NH2 (UFP101), a potent NOP receptor antagonist, on molecular, cellular and behavioural alterations associated with chronic mild stress. J Psychopharmacol 31: 691-703.

Wei WZ, Xie CW (1999) Orphanin FQ suppresses NMDA receptor-dependent long-term depression and depotentiation in hippocampal dentate gyrus. Learn Mem 6: 467-77.

Wichmann J, Adam G, Rover S, Hennig M, Scalone M, Cesura AM, Dautzenberg FM, Jenck F (2000) Synthesis of (1S,3aS)-8-(2,3,3a,4,5, 6-hexahydro-1H-phenalen-1-yl)-1phenyl-1,3,8-triaza-spiro[4. 5]decan-4-one, a potent and selective orphanin FQ (OFQ) receptor agonist with anxiolytic-like properties. European journal of medicinal chemistry $35: 839-51$.

Witkin JM, Statnick MA, Rorick-Kehn LM, Pintar JE, Ansonoff M, Chen Y, Tucker RC, Ciccocioppo R (2014) The biology of Nociceptin/Orphanin FQ (N/OFQ) related to obesity, stress, anxiety, mood, and drug dependence. Pharmacol Ther 141: 283-99.

Yu TP, Fein J, Phan T, Evans CJ, Xie CW (1997) Orphanin FQ inhibits synaptic transmission and long-term potentiation in rat hippocampus. Hippocampus 7: 88-94.

Yu TP, Xie CW (1998) Orphanin FQ/nociceptin inhibits synaptic transmission and long-term potentiation in rat dentate gyrus through postsynaptic mechanisms. J Neurophysiol 80: 1277-84.

Zaveri N (2003) Peptide and nonpeptide ligands for the nociceptin/orphanin FQ receptor ORL1: research tools and potential therapeutic agents. Life Sci 73: 663-78.

Zaveri NT (2011) The nociceptin/orphanin FQ receptor (NOP) as a target for drug abuse medications. Curr Top Med Chem 11: 1151-6. 
Zaveri NT (2016) Nociceptin Opioid Receptor (NOP) as a Therapeutic Target: Progress in Translation from Preclinical Research to Clinical Utility. J Med Chem 59: 7011-28. 


\section{Table 1}

\begin{tabular}{|c|c|c|}
\hline Name & Description of the task & References \\
\hline $\begin{array}{l}\text { Morris Water Maze } \\
(\mathrm{MWM})\end{array}$ & $\begin{array}{l}\text { Used to assess spatial memory. The mouse is } \\
\text { placed in a pool of water where it must learn to } \\
\text { use spatial cues located in the room to navigate } \\
\text { to a submerged platform. The time to reach the } \\
\text { platform decreases across trials and during the } \\
\text { probe test, when the platform is removed, } \\
\text { animals spend more time in the quadrant where } \\
\text { the platform was located. The visible platform } \\
\text { version of the test allows to assess non spatial } \\
\text { components such as swimming ability and } \\
\text { procedural memory. }\end{array}$ & $\begin{array}{l}\text { (Higgins et al. 2002; } \\
\text { Koster et al. 1999; } \\
\text { Kuzmin et al. 2009; } \\
\text { Manabe et al. 1998; } \\
\text { Redrobe et al. 2000; } \\
\text { Sandin et al. 1997; } \\
\text { Sandin et al. 2004) }\end{array}$ \\
\hline $\begin{array}{l}\text { Fear Conditioning } \\
\text { (FC) }\end{array}$ & $\begin{array}{l}\text { Used to assess aversive associative memory. It is } \\
\text { a form of Pavlovian conditioning based on the } \\
\text { association of an aversive stimulus (an electric } \\
\text { shock) with a conditioned stimulus, the context } \\
\text { in which the shock was received (Contextual } \\
\text { FC), or a discrete cue such as a sound (Tone FC). } \\
\text { During the retention test, the freezing behavior } \\
\text { (conditioned response) triggered by the } \\
\text { presentation of the context or the sound is } \\
\text { measured. }\end{array}$ & $\begin{array}{l}\text { (Andero et al. 2013; } \\
\text { Fornari et al. 2008; } \\
\text { Goeldner et al. 2009; } \\
\text { Mamiya et al. 2003; } \\
\text { Ouagazzal 2015; } \\
\text { Rekik et al. 2017) }\end{array}$ \\
\hline
\end{tabular}

Inhibitory Avoidance Used to assess aversive associative memory. (IA) Also called Passive Avoidance. The mouse receives a foot shock when it enters a dark (Adem et al. 2017; Hiramatsu and Inoue 1999; 2000; compartment (step-through version) or steps Hiramatsu et al. down a platform (step-down version). During the 2008; Liu et al. retention test, the animal has to inhibit its natural 2007; Manabe et al. tendency to enter the secure dark environment or 1998; Miwa et al. leave the aversive platform. If it remembers 2009; Miwa et al. receiving the electric shock the step-through or step-down latency should increase. 2010; Roozendaal et al. 2007)

\begin{tabular}{|c|c|c|}
\hline $\begin{array}{l}\text { Object Recognition } \\
\text { (OR) }\end{array}$ & $\begin{array}{l}\text { Used to assess recognition memory. During the } \\
\text { learning phase the mouse is allowed to explore } \\
\text { two identical objects in an open field. During the } \\
\text { test phase, one of the object is replaced by a new } \\
\text { one. If the animal detects the change, and thus } \\
\text { recognize only the familiar object, it will spend } \\
\text { more time exploring the new one. }\end{array}$ & $\begin{array}{l}\text { (Goeldner et al. } \\
\text { 2008) }\end{array}$ \\
\hline $\begin{array}{l}\text { Y-maze, spontaneous } \\
\text { alternation }\end{array}$ & $\begin{array}{l}\text { Used to assess spatial working memory. The } \\
\text { mouse is put in the center of a Y-maze and } \\
\text { allowed to explore it freely without any reward. } \\
\text { If its spatial working memory is intact an animal } \\
\text { is supposed to alternate regularly between the } \\
\text { three arms in order to optimize its exploration } \\
\text { strategy. }\end{array}$ & $\begin{array}{l}\text { (Hiramatsu and } \\
\text { Inoue 1999; 2000; } \\
\text { Mamiya et al. 1999; } \\
\text { Miwa et al. 2009; } \\
\text { Ouagazzal 2015) }\end{array}$ \\
\hline
\end{tabular}


Table 1: Main behavioral paradigms used to assess the memory modulating properties of the N/OFQ system. 